change when economic conditions are improving. Do the members become complacent during an economic upswing and does their satisfaction with the union diminish? The problem with conducting research of this nature is that it requires a commitment to carry out identical surveys with a considerable time gap between them. Further- more, there is no way of predicting in advance the changcs which may occur in the economy between the surveys. Nevertheless, if one or both of the surveys can be carried out in conjunction with some other project the cost would be less and. in any case, the benefits of such research would repay the effort.

\title{
Towards Equal Opportunity Employment For Women in New Zealand \\ *AUDREY SHARP
}

"We in this country have to live on our wits, and half the wits are in female heads, though one would never think so, looking at the way women are distributed throughout the labour market."

-Baroness Seear

\section{INTRODUCTION}

Women make up $50 \%$ of the total population in New Zealand and their numbers in the workforce are rapidly increasing. During the past forty years there has been a marked change in the composition of the labour force. The temale component has increased from $20 \%$ in 1926 to $32.5 \%$ in 1976. As the number of females in employment has increased, so has the composition of women engaged in employment also changed significantly. Married women are now entering the workforce in increasing numbers so that by $197655.8 \%$ of the female labour force was made up of married women. Despite their vastly increased numbers, however, women do not have access to every kind of employment but generally tend to work in a range of jobs that have largely been theirs traditionally. A far wider range of job opportunities is available to men only, both by convention and by the operation of legal restraints, and even in fields where women outnumber men, female workers almost invariably hold positions lower in status and remuneration. If women leave the workforce to have children and care for them, then they may lose not only their wages, but also their service bonuses and incidental benefits such as superannuation and accident compensation. Married women returning to the workforce are also forced to look for other jobs, since very rarely is their old job held open until their return. If women remain at work while their children are young they are often faced with an appalling lack of good child-care and after school facilities coupled with the reluctance on the part of many employers to concede variations in working hours.

\section{EMPLOYER ATTITUDES}

Traditional beliefs and continuing social norms have encouraged employers to treat women and men differently. Although sometimes this different treatment reflects an explicit policy, it more often represents the attitudes employers have towards women. While most employers will now admit that

- AUDREY SHARP is a masters student in political studies at the University of Auckland. The publication of this article marks the oflicial retirement trom the London School of Economics and Political Science of Baroness Seenr, author of the OECD Report on the Employment of Women. 
there are lewer differences between men and women than they once believed, many still continue to view women in stereotyped ways which limit a woman's opportunity for employment and promotion. Several stereotypes underlie many of the traditional beliels ebout women. The first is that a woman's primary commitment is to her famiiy and this commitment limits her effectiveness on the job. Following from this a number of other factors can be listed.

1. That a woman's work will be characterised by interruptions rather than career continuity.

That women will lack the geographical mobility necessary for many jobs.

3. That women will have lower career aspirations than men and will therefore be less productive.

4. That for the three reasons just listed, women will not be good candidates for on-the-job training.1

On the assumption that women will or should place the home and family first. many employers conclude that women will have high rates of turnover and absentee. ism. A second assumption is that women are suited by temperament and skill for certain lobs and not for others, and in varticular those which relate to their role as homemakers.

"The sex linked traits in question may not even be proven traits of ane sex or the other - it is sufficient that employers believe they are, or believe that one sex has an advantage over the others in some important respect . . women are supposed to have greater manual dexterity than men. This may or may not be true, but that is not particularly important. What is important is the extent to which employers believe it, and let belief guide their hiring policies."2

Jobs entalling much physical strength tend to be automatically labelled male. Simmons belleves that except in family or sexual relationships, our social value system dictates that men should not be subordinate to women and that intimate groups; except those based on the family, should be composed of either sex but not both. 3 Perceptions such as this help explain why some companies as well as Police and Fire departments have insisted on keeping certain jobs separate, In addition, emotion is often aroused when the question of a femaie supervising men is discussed, and the desire to prevent women from moving into such positions becomes in some cases a justification for defining whatever work women do as low-level work. The attitudes described above are easily translated into practices that place women at a disadvantage in the workforce and which directly affect employment opportunities.

\section{THE WORK ENVIRONMENT}

In many cases, employers do not directly discriminate against women but rather the nature of the work environment itself is designed for the life styles of men rather than women. Work schedules often accommodate men more easily than women. Flexible working hours are of particular importance to working mothers, yet both employers and unions have at times been reluctant to explore flexible hours for women. Many women are part-time workers and as a result face a number of disadvantages. They may be excluded from benefit programmes, such as health and pension plans, and promotion is often limited on the grounds that part-time workers can assume only limited responsibility because they are not always available to provide necessary supervision. Employers often argue that being permitted to work on a pormanent part-time basis is in itself a benefit, and so why should extra concesstons be given to this group. This belief does not accurately reflect the commitment or productivity of many part-time workers. In times of rising unemployment, "discrimination continues because most employees (for fear of losing their jobs) accepf whatever terms employers dictate, including fulltime work schedules.

\section{WORK WOMEN DO}

In New Zealand women are not represented in all job areas, but are concentrated mainly in three industrial groups: (1) community, social and personal services (teaching ard health services); (2) manulacturing: (3) wholesale and retail trade, res* taurants, hotels (this includes salespeople.

\footnotetext{
1- Simmons, A, Exploitation from 9 to 5 : Report of the Task Force on Women and Employment, New
2- Yorki Lexington, 1975, p. 66 .

3-ibld, p. 67
} 
waitresses). Of all women workers, $78 \%$ are engaged in one of these three groups compared with $55 \%$ of all male workers. Despite cerfain occupations having a heavy concentration of women within them, men are more likely to hold positions of seniority. Thus while 25,573 women and 18,334 men are engaged in teaching, there are nearly ten times as many male head teachers or principals (157 women and 1541 men), plus 164 male state school inspectors compared with nine females. ${ }^{4}$ In coeducational state secondary schoois $42 \%$ of teachers are female but $99.4 \%$ of headmasters are male, suggesting that female heads will only be found in single-sex schools. In state primary schools $62 \%$ of the teachers are women, while $98.5 \%$ of head teachers are men. 5 Inequalities such as this have persisted not only because of the stereotyped attitudes which exist within society at large but because women themselves hold attitudes which reinforce their roles as mothers, housewives and workers in low status jobs.

\section{THE WOMAN'S CHOICE}

More women are consigned to low pay, routine work and poor prospects by their own choice than by the actions of male employers. Even today, despite the many changes that have taken place, the cliche that a woman's place is in the home is believed by many men, and also by many women. Until the beginning of the last century, this was held to be self-evident, mainly because for most people home was where much of the family's income or provisions were made. This is not the case today. Davies notes that the work that women do, and have always done to supplement the family's income has moved away from the home and into the office, the factory and the shop. A separation has occurred between the two parts of the dual function of women; as wife, mother. and as a contributor to the upkeep of the family.' 6 Taday when the family needs extra income, most women have to find employment away from the home which is a clear break with the earlier tradition where the home was the focus of both roles.

Parallel to the physical separation of these two roles there has grown up in the minds of men and women alike, the fear that the economic role of women is possibly superceding her social role. In the case of a married woman, this may be expressed in a feeling of guilt that she should wish to continue working after marriage, or when her children are at school. And she is guilty now, in the present economic situation, of taking jobs that rightfully belong to others - school-leavers, for example. Bill Rowling. November 1977, commenting on rising unemployment stated: "The situation for young people is made more difficult by married women who have stayed on or chosen to re-enter the workforce." This attitude is rarely spelled out so clearly but it is nonetheless widespread. Others may feel that certain jobs or levels of responsibility are inherently unwomanly. For many single girls, work is seen as secondary and subordinate to the business of attracting a husband.

Today most women now have their last child by the time they are 30 , and by the time they are 35 the children are at school. As a result, the amount of free time available to a woman with children of school age is gradually lengthering. For too many women, however, this time is spent working at some dead-end job because they never trained for anything better prior to marriage. While most women are quite willing to work, and indeed industrial society could not function if they were not, the job must be secondary to the social role of mother and wife. They are therefore required to confine themselves to a limited range of employments recognised as acceptable woman's work. These are usually the modern versions of jobs that were carried out in pre-industrial society by women in the home - nursing, teaching, food processing. clothing. The status of women in these employments is generally regarded as secondary and supportative since it is marriage which counts, and this obsession not only influences the choice of career, but also how much responsibility women are prepared to accept in any employment they undertake.

\section{EDUCATION - DOES IT FOSTER INEQUALITIES?}

Research in the field of education points to the crucial role the schools play in the

4-Bunkie, Phyllida, Women at Your Service, N.Z. Listener, May 31, 1975 p. 18

5-ibid.

6-Davies, A., Women and Work, London: Hutchinson, 1975, p. 99 
development of a child's personality. Teachers and classmates develop, reinforce or challenge attitudes about sex roles. In addition the more education a woman has, the more likely she is to work. However. the nature of her education directly influences the kind of work she is likely to seek, as well as the kind of work to which she has access. Equal education opportunity is a prerequisite for equal opportunity in the labour force. Unfortunately education tends to be another barrier to women entering the workforce on an equal basis to men (see table below for an indication of the educational qualifications of women in New Zealand).

TABLE 1

\section{EDUCATION OF WOMEN IN NEW ZEALAND}

With the exception of those holding School Certificate there is a lower percentage of females with secondary school and university qualifications than amongst males. But the gap, insolar as it can be measured by a comparison between the only two recent censuses, whith education, is closing. The following table illustrates the rate of movement in qualifications held by females from 1966 to 1971 during which period the female population of 15 years of age and over increased by 79,619 or 8.8 per cent.

\begin{tabular}{|c|c|c|c|c|c|c|}
\hline \multirow{6}{*}{$\begin{array}{l}\text { Qualification } \\
\text { University - } \\
\text { Doctorate } \\
\text { Master's degree } \\
\text { Bachelor's degree } \\
\text { Diplomas or certificates } \\
\text { Secondary - } \\
\text { University Scholarship, } \\
\text { Bursary, Higher School } \\
\text { Certificate and University } \\
\text { Prelim. Exam. } \\
\text { University Entrance or } \\
\text { Matriculation } \\
\text { School Certificate }\end{array}$} & \multirow{2}{*}{$\begin{array}{l}\text { Males } \\
1966\end{array}$} & \multicolumn{2}{|c|}{ (Percentage) } & \multicolumn{3}{|c|}{ Females (Percentage) } \\
\hline & & 1971 & Increase & 1966 & 1971 & Increase \\
\hline & $\begin{array}{l}0.11 \\
0.50 \\
1.76 \\
0.82\end{array}$ & $\begin{array}{l}0.15 \\
0.58 \\
2.78 \\
0.94\end{array}$ & $\begin{array}{l}48.7 \\
25.2 \\
70.5 \\
23.1\end{array}$ & $\begin{array}{l}0.01 \\
0.22 \\
0.64 \\
0.22\end{array}$ & $\begin{array}{l}0.02 \\
0.26 \\
1.00 \\
0.41\end{array}$ & $\begin{array}{r}50.5 \\
30.7 \\
69.8 \\
100.0\end{array}$ \\
\hline & & & & & & \\
\hline & 1,12 & 1.71 & 64.9 & 0.61 & 1.12 & 98.3 \\
\hline & $\begin{array}{l}3.50 \\
4.72\end{array}$ & $\begin{array}{l}6.41 \\
8.42\end{array}$ & $\begin{array}{l}97.0 \\
92.2\end{array}$ & $\begin{array}{l}2.44 \\
4.87\end{array}$ & $\begin{array}{l}5.48 \\
9.89\end{array}$ & $\begin{array}{l}144.1 \\
120.7\end{array}$ \\
\hline
\end{tabular}

Source: Social Trends in New Zealand, 1975

From the day children first enter school. they learn about traditional sex roles. Sometimes the ways in which schools condition boys and girls is cbvious, Often they are not. An American study of the different roles of women that children are presented with in books concluded that such books do not present girls with varied role models of working women

'Thus, there are few role models available to the little girl who thinks it might be interesting to work. In the great majority of books there are simply no working women: all of the females are found with that ubiquitous apron. However, even in the rare book. where there were some working women, all of these were shown in a limited number of stereotyped feminine occupations: they were the nurse, not the doctor: the stewardess, not the pilot; the secretary, not the executive,"7

This situation is changing, however, as more children's books with a women's viewpoint begin appearing. Nevertheless, the stereotyped roles we ascribe to males and females continue to persist, reinforced by other elments within the education system.

Vocational Guidance Counsellors, like most teachers, pass on their own beliefs about male and female roles and careers. Unfortunately, these beliefs often cause them to encourage students to fit into sex stereotyped roles, regardless of the student's individual interest and abilities. Higher 7- Weitzman, L J. 'Sex Role Socialization in Children's Books,' (Paper prepared for meoting of the
American Sociological Association) Aug. 1971, quoted in Simmons, p. 149. 
education and specialised training are viewed by many schools and parents as less important for females than for males, on the theory that all women marry and that all wives are financially dependent on their husbands. This ignores the fact that in New Zealand in 1971, 34,098 familios were headed by females (that is, families with one parent being permanently absent, usually the male). If one takes into account the amount of money that is now being paid by the government to solo-parents, the number of women acting as heads of families will surely have trebled. In 1976. widowed, divorced and separated women in New Zealand made up a sobering total of over 190,000. Added to this is the fact that one in three marriages end in divorce which in turn has affected at least 12,000 children. Women are only gradually realising that even if they marry and have no immediate financial need to work, that the need may yet arise. Therefore the type of education a wonan has, and the availability of re-training programmes for women re-entering the workforce, is essential if we are to approach anything along the lines of equality of opportunity.

\section{LEGAL STATUS AND GOVERNMENT REGULATIONS}

Legally there exist certain impediments to women attaining equal opportunity of employment. Statutory provisions and awards restricting the hours women may work (in accordance with I.L.O. conventions), the weights they may lift, and even the nature of work they may do, are currently in force. They reflect a curiously ambivalent attitude to women's capabilities and are but one more way in which women are prevented from seeking equal opportunity in employment.

The Factories Amendment Act, 1972 (s. 19) limits the hours that women can work at night in factories. It provides that for 11 consecutive hours, 7 of which must be between 10 p.m. and 7 a.m., women are prohibited from working. There is of zourse no comparable restriction on men. Although this legislation was enacted with the commendable aim of protecting women from sweated labour conditions, its effect is to deprive women of the opportunity to earn maximum overtime rates in factories. Women can work all night as nurses, telephone operators and waitresses, but cannot drive taxis, buses etc, between sunset and sunrise
There exist restrictions on the weight women may lift, on the nature of work they may perform, and some laws discriminate unnecessarily in favour of women. For example, the practice which exists in some firms of giving the women workers one helf day off work each month so they can do their shopping. This type of positive' discrimination causes justifiable resentment among male co-workers, causing more damage than good to the woman's cry for equality of opportunity in employment. On the whole, legislation on the above lines has been found not only unnecessary, but discriminatory towards both men and women. Other areas where the law discriminates against women in employment derive from the idea of women as dependents.

The superannuation and accident compensation schemes are designed to serve full-time earners. Women who take time off from paid employment to bring up a family lose out on superannuation, and women whose life work has been devoted to the home in unpaid, but nevertheless essential employment, have to depend ultimately on social security. In some cases, private industrial super schemes have not been available to female employees, despite their work record.

If a married woman loses her job through illness or because of uncertain economic conditions she is theoretically entitled to unemployment benefit. The means test applied to the family however cuts out most women, unless her husband earns a pittance, and unfortunately the income of a working wife today is not just pin money but is in many cases essential to the family budget.

Another aspect of this male breadwinner/female dependent syndrome is in the Public Services Regulations, 1964. Under regulation 56 (2) the State Services Commission may make specific rules regarding the transfer of persons who are not breadwinners. This the Commission has interpreted as meaning persons who are not male. A government department will meet transfer expenses of the employee and his family, but transfer expenses for married women employees have to be referred to the Commission with details of circumstances, numbers and ages of children and previous and proposed occupation of the husband. If circumstances are found 
to be difficult (in other words, the male can't pay), the transfer costs will be paid. Under Education (staff and salaries) Regulations, 1957, the education manual allows for the removal expenses for married women only if her husband is totally dependent on her. Regulations along these lines are totally discriminatory towards women and do not take into account the value of the woman within the workplace, 8

\section{MATERNITY LEAVE AND CHILD-CARE FACILITIES}

Only one quarter of the total number of married women in employment are under 30 years old. It seems both unjust and unnecessary to penalise women for the relatively short time they are out of paid employment by assuming that when they leave to have children, they will not return. This injustice expresses itself in concrete terms in the overall lack of provision for maternity leave $(86 \%$ of awards in 1976 made no mention of maternity leave at all). although there are exceptions such as for teachers. After childbirth, the majority of women must hunt for new jobs.

Many women today return to the workforce while their children are still dependent and it has been estimated that some 35-40,000 women with pre-school children are in paid employment. In New Zealand there are 134 day-care centres registered with the department of Social Welfare which cater for a total of 2781 children. This num ber is highly inadequate and does not even begin to serve the needs of women.

Adequate and good child-care facilities are essential if women are to have equal employment opportunities, In part because of this lack of child-care, employers are reluctant to hire mothers, place them in positions of responsibility, or provide them with training opportunities. Some mothers have been unable to enter the workforce at all because they cannot make satisfactory arrangements for the care of their children. The availability of child-care however, does not mean that all womer will work, but it does mean that all women will have the opportunity to work if they so choose

\section{STEPS TOWARDS EQUAL OPPORTUNITY EMPLOYMENT FOR WOMEN}

The attitudes which dictate the present situation of women in New Zealand are entrenched in our collective consciousness. Unfortunately beliefs of this nature are the hardest to change. In addition the present economic downturn in this country has put women under increased pressure either to take what jobs they can (even if they are inferior and poorly paid) or to join the ranks of the unemployed (in June this year, $42 \%$ of the unemplayed were women). Although I see no real end to the dis. criminatory practices that exist within this country under the present 'profit-orientated' system, certain measures if enforced through governmental legislation could at least improve a woman's lot.

1. The repeal of 'protective' labour legislation except insofar as it is necessary for all workers irrespective of sex.

2. Some investigation into superannuation schemes and trade union awards which operate to the disadvantage of women, and improvements implemented. In France women are allowed to leave their work for up to two years after the birth of a child and to return to the same job without losing any benefits or promotion opportunities.

3. Uniform provision for maternity leave for all women having children should be made if they have worked for at least nine months prior to pregnancy. This provision could be along the lines of schemes operating in Europe. In France for example, a woman is entitled to six weeks leave prior to the birth and eight weeks after with full pay and a guarantee of her old job back. In East Germany, the couple are given a choice as to who is to stay home and if the child cannot be placed in one of the state run creche's, the woman or man is allowed to remain at home on full pay until a place is found for the child

4. In-service training schemes for women returning to the workforce should be set up and where necessary sponsored by the government.

5. Good child-care facilities should be provided near the workplace in

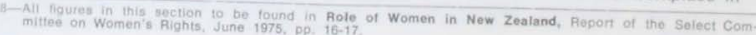


a way that caters adequately for all areas of New Zealand.

6. Possibly a programme of 'Glide Time' could be introduced for both men and women so that at least one parent is available to stay home where necessary. that is when the child is sick or on holiday.

Many of the barriers which women face in employment are ones that have been created by our 'profit-orientated' system. and it can in fact be argued that by desiring to enter the workforce women are heading towards greater enslavement than that which is experienced in the home. Social attitudes begin to be formed in the home. They are then reinforced at school, where boys and girls undertake different activities and attain different levels of educational achievement. Because of the disparity in their education and training. because of their respective expectations about their future roles in society and because they lack any economic power, the position of men and women continues to be divided with women occupying the less skilled, less responsible and lower status jobs.

Dr Erich Geiringer ${ }^{9}$ argues that our industrial and profit-orientated system has been responsible for women entering the workforce since employers saw them as a cheap labour reservoir which could be easily exploited. Industrialists firstly equalised pay as a bait and bandied around the concept of equality. Despite women entering the workforce in increasing numbers, however, industrialists continued to adhere to the old and well proven work patterns which were based on the characteristics of male labour and which meant in effect that, although women received in theory equal pay, in practice they were not given equal work but heid the lowest paid jobs. As more women were drawn into the pro- cess, the economic situation took a downturn so that what had begun as a 'financial perk' became an 'economic necessity.' Since no adequate provision was made to retain an appropriate labour force in the home situation an increasing number of women found themselves not only doing a full-time industrial job but also the housework on top. The result has been that women have become trapped in a situation which is even more oppressive than the one which they wanted to be 'liberated' from.

The only answer that Geiringer sees to this rather messy situation facing all women today, is for women to be given a real choice in employment. Because the 'childbearing and child-rearing part of our economy is a depressed industry and the workers in it do not enjoy the most fundamental rights accorded to workers in every other area of our economy, 10 it is little wonder that women clamour to leave the home and enter the industrial workforce. The situation is not much better there, however, and until women are given a real choice and no longer 'jump' to the industrialists cry. then the barriers which exist will continue to remain.

I would advocate upgrading women's role in the home and increasing the status associated with this role by paying women a realistic wage for the work they do in the home so that future generations no longer see 'poor old mum' as a second class citizen and take on that viewpoint themselves. Once women's role in the home is upgraded. women's position in sociely as a whole will benefit and women will no longer lack the economic power which relegated them to second class citizenship in the first place. In fact, the many barriers which exist will no longer be relevant since women will at last get recognition in their own right instead of constantly having to ape men. $\cdot$

9-Geiringer, E., Speech reprinted in N.Z. Economist, June 1974, pp. 45.8. 10 - ibid, p. 47 . 